\title{
The effect of malnutrition on the pattern of growth in the rat kidney and the renal response to acidosis
}

\author{
By H. S. FRASER ANd G. A. O. ALLEYNE \\ Tropical Metabolism Research Unit, University of the West Indies, \\ Kingston 7, Jamaica, West Indies
}

(Received 8 May I972-Accepted 31 May 1973)

\begin{abstract}
I. The kidneys of normal rats were analysed for water, fat, protein, RNA and DNA, at Io, 21 and $36 \mathrm{~d}$ after birth. The effects on growth caused by two types of malnutrition were investigated.

2. An increase in the RNA:DNA ratio was demonstrated between ro and $36 \mathrm{~d}$, contrary to previous evidence that this ratio is fixed at birth.

3. Energy deficiency during the first $2 \mathrm{I} d$ of life resulted mainly in fewer kidney cells, whereas protein-energy deficiency between 21 and $36 \mathrm{~d}$ resulted mainly in a smaller cellular content of RNA and protein.

4. In response to metabolic acidosis, both groups of malnourished rats increased urinary excretion of ammonia and there was enhanced gluconeogenesis in vitro; the basal rate of gluconeogenesis was lower in the protein-energy-deficient rats than in the controls.

5. Protein-energy-deficient rats did not exhibit the renal hypertrophy shown by the control rats in response to acidosis.
\end{abstract}

Malnutrition in children or adults affects the function of the kidneys in several ways. Glomerular filtration rate and renal plasma flow are reduced (Gordillo, Soto, Metcoff, Lopez \& Antillon, 1957; Alleyne, I967) and there is impairment of the capacity to acidify or concentrate the urine (Smith, I959; Klahr, Tripathy \& Lotero, 1970). In adult rats which have been fed on a low-protein diet there are also changes in renal functions; for example, there is a reduction of glomerular filtration rate, and an inability to excrete a water load rapidly (Dicker, 1950; Schneiden, Hendrickse \& Haigh, 1958). There is no information, however, on renal function in malnourished young rats.

Before any detailed investigations are carried out on the effect of malnutrition on the function or metabolism of the kidneys of young rats, it is appropriate to examine first the kidneys of normal rats and the results of malnutrition on the growth pattern and composition of the kidney. If any such studies are to be related to man, it is also necessary to consider the type of malnutrition which is induced. Winick \& Noble (1965) studied the growth pattern of the kidneys of rats which were normal or had been made malnourished by the technique of Kennedy (1958), in which a mother suckles eighteen to twenty young rats. Widdowson, Dickerson \& McCance (1960) examined the kidneys of young pigs which were made malnourished by being given restricted amounts of a normal diet. In both of these experiments the animals were essentially energy deficient. There is no information on renal growth in young animals which are mainly protein-energy deficient.

The present experiments investigated in the rat the effects of two types of malnutrition on renal growth and composition, and the manner in which malnutrition affects renal ammonia production, gluconeogenesis and hypertrophy in response to metabolic acidosis. 


\section{METHODS}

All rats were bred in our own laboratory from the Sprague-Dawley strain, imported from Charles River Laboratories (Wilmington, Mass., USA). Normal growth curves for our colony were established by weighing rats at $x 0,2 \mathrm{r}$ and $36 \mathrm{~d}$, and were found to match the curves provided by the exporters. Only litters which conformed with the standard curves were used as normal controls, or used to produce malnourished animals. Mothers and weanling rats not on protein-deficient diets were fed on Purina Laboratory Chow which contained $23 \circ \mathrm{g}$ protein $/ \mathrm{kg}$. Two models of malnutrition were used.

\section{Energy-deficient rats}

The technique used by Kennedy (I958) and Widdowson \& McCance (1960) was applied to litters on the Ist day post partum; the young from two or three litters were mixed so that one mother suckled eighteen to twenty. This method has the disadvantage that there is a tendency for the more aggressive animals to obtain more milk (Miller, 1969), which results in a number of deaths and a wide range of weights at weaning; from almost normal to one-third of normal weight for age. It was therefore decided to accept as malnourished only animals of less than two-thirds of the usual weight at weaning, that is less than $30 \mathrm{~g}$ at $2 \mathrm{I} \mathrm{d}$. Approximately one-third of the survivors at $2 \mathrm{I} \mathrm{d}$ satisfied this criterion. These animals are referred to as energy deficient. Controls were $2 \mathrm{I}$-d-old rats of normal weight (see Table $\mathbf{r}$ ), suckled in litters of eight. Throughout these studies, no attention was paid to the sex of the rats.

\section{Protein-energy-deficient rats}

Rats were suckled in litters of eight and killed $\mathrm{I} 5 \mathrm{~d}$ after having been weaned at $2 \mathrm{I} \mathrm{d}$ on to a diet which was taken $a d$ lib. and contained $10 \mathrm{~g}$ protein $/ \mathrm{kg}$. Such a model has been used previously for studies on lipid metabolism by Flores, Sierralta \& Monckeberg ( 1970 ). The composition of the diet was $(\mathrm{g} / \mathrm{kg})$ : maize starch, 540; glucose, I 50 ; lard, I 50 ; wheat flour (lysine content $2.48 \mathrm{~g} / \mathrm{kg}$ ), I00; mineral mixture, 50 ; vitamins, IO. The composition of the mineral mixture was $(\mathrm{g}) \mathrm{NaCl}, 22 ; \mathrm{CaHPO}_{4} . \mathrm{H}_{2} \mathrm{O}, \mathrm{I}_{3} \mathrm{O}$; potassium citrate $\left(\mathrm{K}_{3} \mathrm{C}_{6} \mathrm{H}_{5} \mathrm{O}_{7} \cdot \mathrm{H}_{2} \mathrm{O}\right)$, ${ }_{2} 5 ; \mathrm{MgSO}_{4} \cdot{ }_{7} \mathrm{H}_{2} \mathrm{O}, 30 ; \mathrm{Fe}$ citrate, $5^{\circ} \circ$; and traces, 0.7. Traces: (g) KI, I2; NaF, Io; $\mathrm{MnSO}_{4} \cdot \mathrm{H}_{2} \mathrm{O}, 2 ; \mathrm{Cu}_{2} \mathrm{I}_{2}, \mathrm{I} ; \mathrm{ZnSO}_{4} \cdot 7 \mathrm{H}_{2} \mathrm{O}, \mathrm{r}$. The vitamin mixture contained (per $\mathrm{kg}$ ) thiamin hydrochloride $60 \mathrm{mg}$, riboflavin $200 \mathrm{mg}$, pyridoxine hydrochloride $40 \mathrm{mg}$, calcium pantothenate $\mathrm{I} \cdot 2 \mathrm{~g}$, nicotinic acid $5 \mathrm{~g}$, myo-inositol $4 \mathrm{~g}, p$-aminobenzoic acid $\mathrm{I} 2 \mathrm{~g}$, biotin $4 \mathrm{mg}$, folic acid $40 \mathrm{mg}$, cyanocobalamin I $\mathrm{mg}$, choline $2.4 \mathrm{~g}$.

\section{Killing of animals}

The rats that were used for the study of kidney composition were killed by cervical dislocation. In other experiments, animals were anaesthetized with sodium pentobarbital (4o mg/kg body-weight) injected intraperitoneally, and when necessary, blood was taken from the abdominal aorta into heparinized syringes. 


\section{Kidney composition}

Animals were killed, then the kidneys were quickly excised, decapsulated, and placed in a covered Petri dish which stood on ice. Pairs of kidneys were blotted on filter-paper and weighed to the nearest $\mathrm{mg}$. Each pair of kidneys was divided into weighed portions for measurement of water, fat, protein, RNA and DNA.

\section{Production of acidosis}

Test animals were given $50 \mathrm{ml} / \mathrm{kg}$ body-weight of aqueous $0.2 \mathrm{M}$-ammonium chloride at intervals of $12 \mathrm{~h}$; control animals were given an equal volume of $0.154 \mathrm{M}$ sodium chloride solution. These solutions were administered intragastrically and the animals were allowed access to their diets. In the studies on ammonia production the animals were given three doses of $\mathrm{NH}_{4} \mathrm{Cl}$ solution; four doses were given to those rats from which kidneys were taken for measurement of gluconeogenesis. In the studies on renal hypertrophy, groups of control or protein-deficient 36-d-old rats were given a $0 \cdot 3 \mathrm{M}-\mathrm{NH}_{4} \mathrm{Cl}$ solution. They were killed $\mathrm{I} 2 \mathrm{~h}$ after the 4 th dose. In preliminary experiments it was shown that $0.3 \mathrm{M}-\mathrm{NH}_{4} \mathrm{Cl}$ was preferable to $0.2 \mathrm{M}-\mathrm{NH}_{4} \mathrm{Cl}$ as a stimulus to renal hypertrophy; hence the rats were given $50 \mathrm{ml}$ of the former solution per $\mathrm{kg}$ body-weight.

\section{Urine collection}

Immediately after the last dose of $\mathrm{NH}_{4} \mathrm{Cl}$ or $\mathrm{NaCl}$ rats were placed in individual metabolism cages without food or water, and urine was collected for a further $6 \mathrm{~h}$ and stored under paraffin with a small quantity of phenyl mercuric nitrate as preservative. At the end of the collection period, the funnel and urine collector were washed with $4^{\circ} \circ \mathrm{ml}$ distilled water and the washings were collected separately.

\section{Gluconeogenesis in vitro}

Rats were killed by cervical dislocation, kidneys were removed, weighed, and then placed in $0.154 \mathrm{M}-\mathrm{NaCl}$ at room temperature. Slices of kidney cortex were cut by hand with a Stadie-Riggs microtome blade. Individual slices were placed in $50 \mathrm{ml}$ Erlenmeyer flasks which contained $5^{\circ} \mathrm{O} \mathrm{ml} \mathrm{Krebs--Ringer} \mathrm{bicarbonate} \mathrm{buffer} \mathrm{which} \mathrm{had} \mathrm{been}$ gassed with a mixture of $\mathrm{O}_{2}$ and $\mathrm{CO}_{2}(95: 5)$ and was at $\mathrm{pH} 7 \cdot 4$. The substrate was glutamine at a concentration of Io mM. The flasks were flushed with the gas mixture, stoppered and incubated in a shaking incubation-bath at $37^{\circ}$ and 100 oscillations/min. After I $h$ slices were removed onto a weighed planchet and $0.5 \mathrm{ml}$ perchloric acid solution ( $100 \mathrm{ml} / 1$ ) was added to each flask. Glucose was measured in the supernatant fraction obtained after the contents of the flask had been centrifuged. The kidney slices were dried for $2 \mathrm{~h}$ at $100^{\circ}$ and then weighed in order to obtain the dry weight. Net glucose production represents the difference in glucose production between slices incubated with and slices incubated without substrate. 
Table 1. Relationship between kidney weight and body-weight, water, fat and protein contents of the kidney of normal rats at $10,2 \mathrm{I}$ and 36 d of age

(Mean values with their standard errors for six rats)

Mean
Mody-wt (g)

\section{Chemical methods}

Water content was determined by drying at $100^{\circ}$ for $24 \mathrm{~h}$. Samples for protein determinations were frozen immediately and subsequently analysed by the method of Lowry, Rosebrough, Farr \& Randall (195I) after digestion by warming in 0.5 $\mathrm{M}-\mathrm{NaOH}$. Samples for fat determination were frozen and analysed subsequently by the method of Stern \& Shapiro (r953). Portions for RNA and DNA determinations were extracted and analysed immediately by methods described by Munro \& Fleck (r 969).

Blood $\mathrm{pH}$ was measured at $38^{\circ}$ in a Radiometer Astrup micro $\mathrm{pH}$ assembly (Radiometer, Copenhagen, Denmark). Plasma $\mathrm{CO}_{2}$ was measured manometrically in a Natelson microgasometer (Scientific Industries Inc., Springfield, Mass., USA). Glucose was estimated using the glucose oxidase method (Huggett \& Nixon, I957) and urine ammonia by microdiffusion analysis (Conway, 1957).

\section{Statistical analysis}

Results are given as means and standard errors of the mean. The significance of the difference between means was calculated by Student's $t$ test.

\section{RESULTS}

Well-nourished animals

Between 10 and $2 \mathrm{I}$, body-weight more than doubled, and it had doubled again by $360 \mathrm{~d}$. Between 21 and $36 \mathrm{~d}$ there was a significant decrease in kidney weight $/ \mathrm{g}$ bodyweight (Table $\mathrm{r}$ ). In the kidney, water content/g wet weight fell between Io and $2 \mathrm{I}$, while fat content per g rose (Table I). Protein/g wet weight increased from 129 to I63 $\mathrm{mg}$ between 10 and $36 \mathrm{~d}$ and total protein in the kidney, like body-weight, increased almost fivefold.

Whereas RNA and DNA increased between Io and $2 \mathrm{I} d$ at a similar rate, the increase in RNA between 21 and $36 \mathrm{~d}$ was greater than that of DNA, and the value for 
Table 2. Weights of kidneys and their total contents of protein, DNA and RNA and the ratios of kidney weight, and $R N A$ contents of kidney to $D N A$ content in normal rats at ro, 21 and $36 d$.

(Mean values with their standard errors for six rats)

\begin{tabular}{|c|c|c|c|c|c|c|}
\hline & & & Age 0 & rat (d) & & \\
\hline & & & & & & \\
\hline Weights: & Mean & SE & Mean & SE & Mean & SE \\
\hline Kidney (mg) & $2 I_{3}$ & $13^{* * * *}$ & $59 \mathrm{I}$ & I 4 ttt & 993 & 19 \\
\hline Protein (mg) & $33 \cdot 7$ & $I \cdot 0 * * *$ & $89 \cdot 8$ & $3.6+t \dagger$ & 166.4 & $7 \cdot 4$ \\
\hline RNA (mg) & I.5I & $0.08 * * *$ & 3.86 & o.09tt+ & 5.40 & 0.18 \\
\hline DNA (mg) & $2 \cdot 24$ & $0.10 * * *$ & $4^{*} 93$ & O.IItt & $5 \cdot 63$ & 0.18 \\
\hline Weight ratios & & & & & & \\
\hline RNA: DNA & 0.68 & $0.0 \mathrm{I} * * *$ & 0.78 & $0.01+\uparrow$ & 0.96 & 0.03 \\
\hline Kidney:DNA & 95.0 & $2 \cdot I^{* * *}$ & 120.0 & I.4tt+ & 176.6 & $3 \cdot 5$ \\
\hline
\end{tabular}

Significance of difference between 10 and $21 \mathrm{~d}: * * P<0.001$.

Significance of difference between $2 \mathrm{I}$ and $36 \mathrm{~d}$ : $+\uparrow P<0.01 ;+1+P<0.001$.

RNA reached the same absolute value as that for DNA by day 36 . The ratios RNA: DNA and kidney weight:DNA increased significantly between 10 and $2 \mathrm{I} d$ and again between 21 and $36 \mathrm{~d}$ (Table 2 ).

\section{Effects of dietary restriction (Table 3 )}

The energy-deficient rats were significantly smaller and thinner than normal weanling rats at $21 \mathrm{~d}$. Miller ( 1969 ) suggested that protein is the limiting factor in rats malnourished in this way, but our animals showed none of the special features of protein depletion. Body-weight and kidney weight were half those of controls, so that kidney weight relative to body-weight was unchanged. Total protein, RNA and DNA were also about half the control values.

The protein-energy-deficient rats were lighter at $36 \mathrm{~d}$ than when they had been weaned, developed steatorrhoea and fatty livers, appeared hungry, ate their fur and were very aggressive, but they did not develop oedema. Analysis of their kidneys showed that all components were significantly less than in the controls at $3^{6} \mathrm{~d}$. The kidneys represented a high porportion of the body-weight, but analysis of them showed that all components were significantly less than in organs of the controls.

\section{Acidosis and urinary ammonia}

The acid-base status, urine $\mathrm{pH}$ and ammonia excretion of the control and energydeficient rats are shown in Table 4 . In both control and malnourished rats, $\mathrm{NH}_{4} \mathrm{Cl}$ produced a metabolic acidosis and a reduction in urine $\mathrm{pH}$. The ammonia excretion of the malnourished rats that were given saline was twice that of the control rats similarly treated, but in both groups acidosis led to an increase in urinary ammonia. The absolute value, however, was higher in the malnourished rats. This pattern was maintained when the urinary ammonia was related to body-weight or kidney weight. 


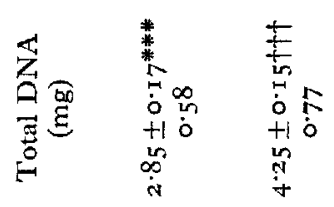

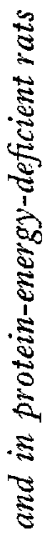

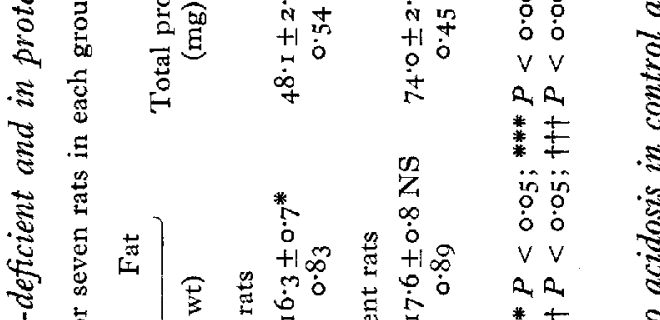

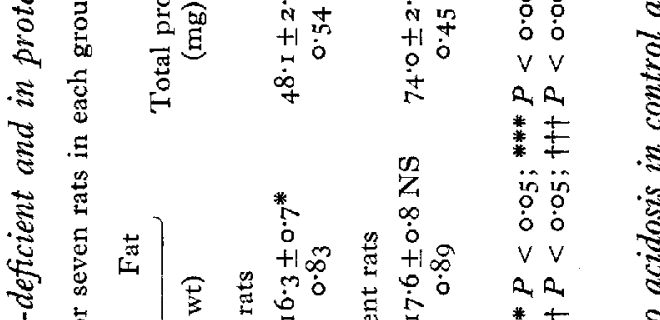

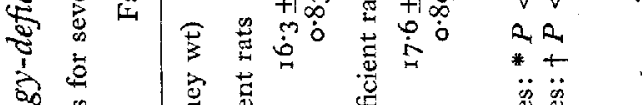

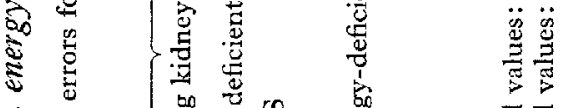

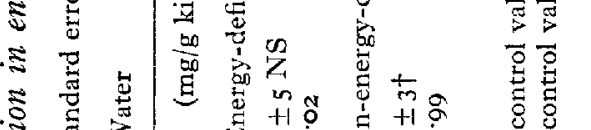

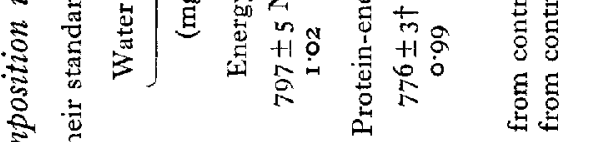

है

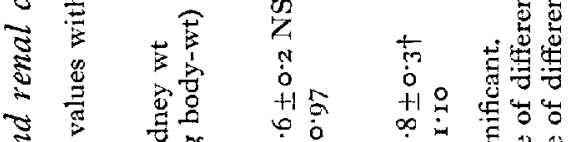

है

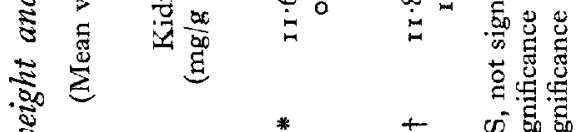

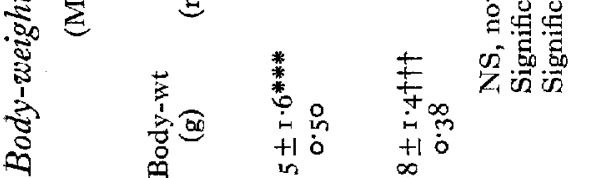

$\stackrel{\dot{0}}{\stackrel{2}{0}}$

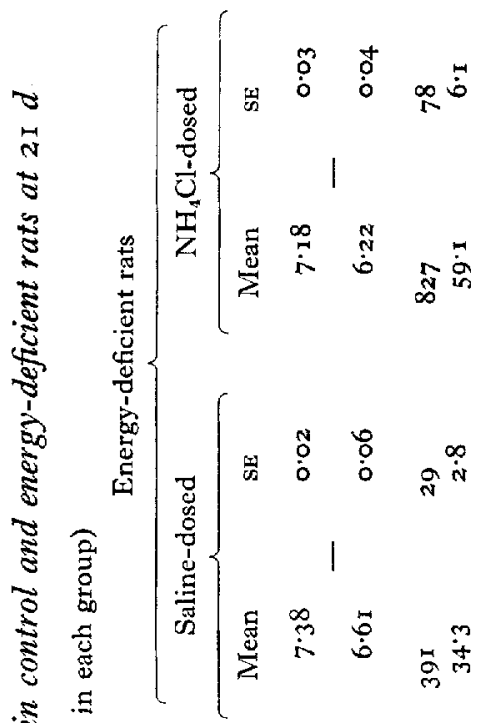

. ‥

焉

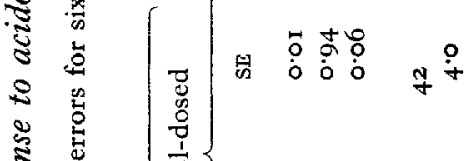

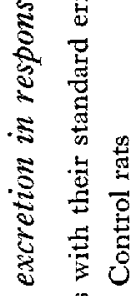

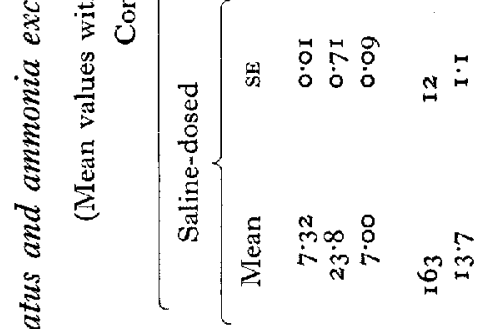

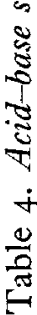

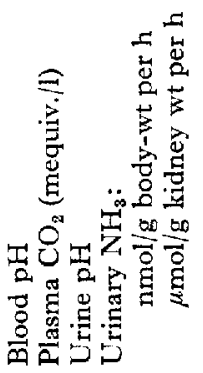


Vol. 3 I

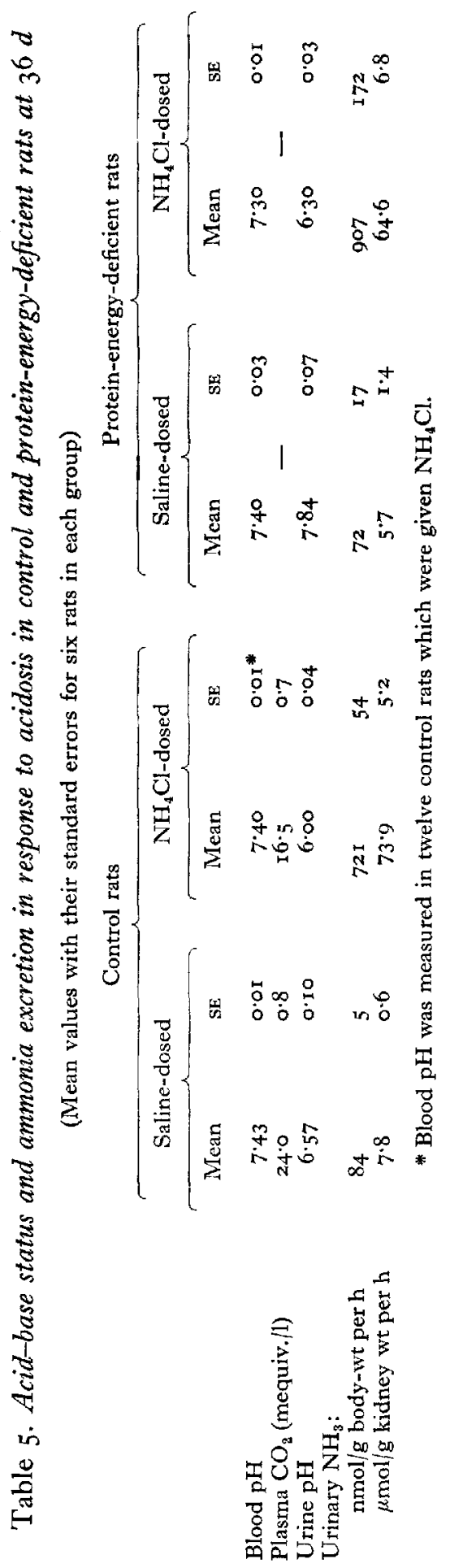


Table 6. Renal gluconeogenesis in response to acidosis in control, energy-deficient and protein-energy-deficient rats

\begin{tabular}{|c|c|c|c|c|}
\hline \multirow{2}{*}{\multicolumn{2}{|c|}{ Treatment }} & \multirow[t]{2}{*}{ No. rats } & \multicolumn{2}{|c|}{$\underset{(\mu \mathrm{mol} / \mathrm{h} \text { per } \mathrm{g} \text { dry kidney wt })}{\text { Net glucose production }}$} \\
\hline & & & Mean & SE \\
\hline \multirow{2}{*}{ 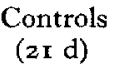 } & Saline & 6 & $28 \cdot 2$ & $2 \cdot 1$ \\
\hline & $\mathrm{NH}_{4} \mathrm{Cl}$ & 6 & $49 \cdot 3$ & $6 \cdot 1$ \\
\hline \multirow{2}{*}{$\begin{array}{l}\text { Energy- } \\
\text { deficient }\end{array}$} & Saline & 6 & $30 \cdot 8$ & $2 \cdot 8$ \\
\hline & $\mathrm{NH}_{4} \mathrm{Cl}$ & 6 & $54 \div 5$ & $5^{\cdot 1}$ \\
\hline \multirow{2}{*}{$\begin{array}{c}\text { Controls } \\
\left(3^{6} \mathrm{~d}\right)\end{array}$} & Saline & 12 & $28 \cdot I$ & $3 \cdot 2$ \\
\hline & $\mathrm{NH}_{4} \mathrm{Cl}$ & II & $67 \cdot 8$ & $3 \cdot 4$ \\
\hline \multicolumn{5}{|l|}{ Protein- } \\
\hline deficient & $\mathrm{NH}_{4} \mathrm{Cl}$ & I I & $63 \cdot 9$ & $6 \cdot 2$ \\
\hline
\end{tabular}

Blood $\mathrm{pH}$ was the same in the saline-dosed control and protein-energy-deficient rats (Table 5). $\mathrm{NH}_{4} \mathrm{Cl}$ produced a significant reduction in blood $\mathrm{pH}$ in the proteinenergy-deficient rats, but not in the controls. This finding was confirmed in several experiments; however, the plasma $\mathrm{CO}_{2}$ in $\mathrm{NH}_{4} \mathrm{Cl}$-dosed control rats did fall to I6. $5 \pm 0.7$ mequiv. 1 (mean $\pm \mathrm{SE}, n=7$ ), compared with $24^{\circ} 0 \pm 0.8$ (mean $\pm \mathrm{sE}, n=6$ ) for saline-dosed control rats. Urine $\mathrm{pH}$ in both groups fell after $\mathrm{NH}_{4} \mathrm{Cl}$ was given. There was a marked increase in urinary ammonia excretion in both groups of animals given $\mathrm{NH}_{4} \mathrm{Cl}$ and there was no difference between the values reached.

\section{Gluconeogenesis in vitro}

The rates of gluconeogenesis in the $2 \mathrm{I}-\mathrm{d}$-old control and energy-deficient rats that were given saline were identical, and similar to those found in kidney slices from the control $3^{6-d-o l d ~ r a t s ~(T a b l e ~ 6) . ~ H o w e v e r, ~ g l u c o n e o g e n e s i s ~ w a s ~ l o w e r ~ i n ~ t h e ~ p r o t e i n-~}$ energy-deficient rats aged $3^{6} \mathrm{~d}$ given saline. In all rats acidosis led to an increase in gluconeogenesis.

\section{Renal hypertrophy in response to acidosis}

These experiments were made with 35 -d-old controls and protein-energy-deficient rats. $0.3 \mathrm{M}-\mathrm{NH}_{4} \mathrm{Cl}$ produced a metabolic acidosis in both groups of animals, as shown by reduction in blood $\mathrm{pH}$ and plasma $\mathrm{CO}_{2}$ (Table 7). A significant reduction in blood $\mathrm{pH}$ was produced in control rats and not in those shown in Table 5 because $\mathrm{NH}_{4} \mathrm{Cl}$ was given in greater quantity and for a longer period of time. In the normal animals kidney weight $(\mathrm{mg} / \mathrm{g}$ body-weight) increased in response to acidosis, but there was no change in the value for the protein-energy-deficient rats. Protein and RNA contents as well as protein:DNA and RNA:DNA ratios increased in the controls but not in protein-deficient rats (Table 8). There was no change in DNA content in either group. 


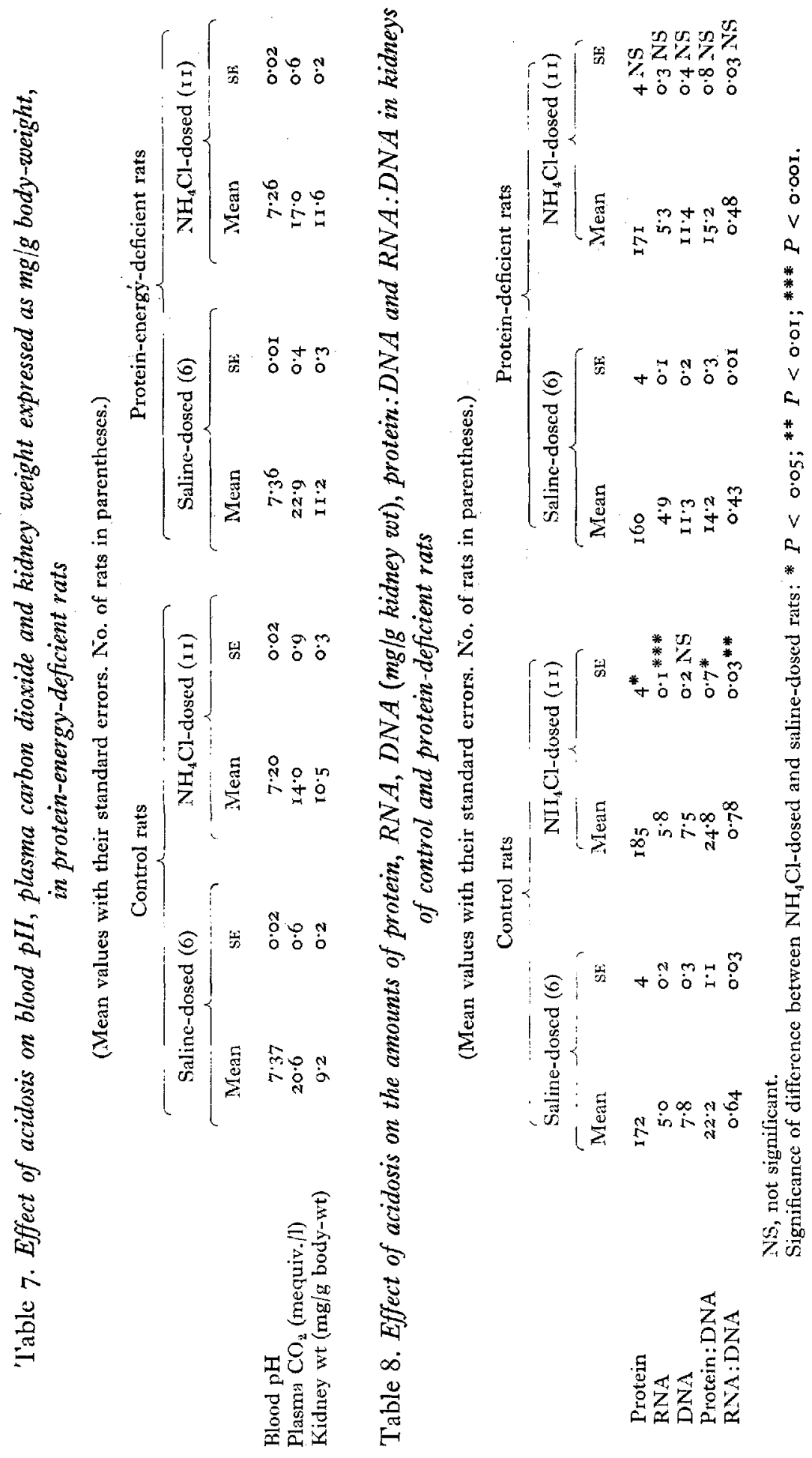


Table 9. Differences between protein, RNA and DNA contents expressed as deficit ratios* in $2 \mathrm{I}-d$-old protein-energy-deficient and $3^{\circ-d \text {-old control rats }}$

\begin{tabular}{|c|c|c|}
\hline & \multicolumn{2}{|c|}{ Deficit ratio } \\
\hline & $\begin{array}{c}\text { Protein-energy } \\
\text { deficient }\end{array}$ & $\begin{array}{l}\text { Protein } \\
\text { deficient }\end{array}$ \\
\hline Protein & 0.47 & 0.55 \\
\hline RNA & 0.54 & 0.61 \\
\hline DNA & 0.43 & 0.25 \\
\hline RNA:DNA & 0.17 & 0.50 \\
\hline Protein:DNA & 0.08 & 0.42 \\
\hline Kidney wt:DNA & 0.17 & 0.45 \\
\hline
\end{tabular}

\section{DISCUSSION}

These results give some information about growth in the rat kidney between ro and $36 \mathrm{~d}$ of age. Kidney weight expressed per $\mathrm{kg}$ body-weight was higher at $2 \mathrm{I} \mathrm{d}$ than at ro or $36 \mathrm{~d}$. Total protein increased fivefold and protein expressed per $\mathrm{kg}$ kidney weight increased from 129 to $163 \mathrm{~g}$. These values are similar to those found by Burch, Kuhlman, Skerjance \& Lowry (1971). Whereas protein increased, water content fell, as Spray \& Widdowson (i950) showed for the body as a whole.

The increase in total DNA followed a pattern described by other workers (Enesco \& Leblond, I962; Winick \& Noble, 1965), increasing most rapidly in the first 2I $\mathrm{d}$ and more slowly after that. However, the absolute amount of DNA was higher than that reported by the latter authors, who used rats of the same strain and at ages similar to ours. The amount of RNA in the kidneys was two-thirds that of DNA at ro d, but increased at a uniform rate to reach the same absolute value by $36 \mathrm{~d}$. Thus the ratio RNA:DNA increased with age - a finding which is opposite to the results obtained by Winick \& Noble (1965), who showed that this ratio was fixed from birth for all organs except liver. Our findings agree with the results of Priestley \& Malt (I968) for mouse kidney and with the general principles of organ growth presented by Miller ( 1969 ).

The ratio kidney weight:DNA can be used as an index of cell size. Enesco \& Leblond (1962) found an increase in this ratio between 19 and $34 \mathrm{~d}$ only. Our results showed a highly significant increase between $\mathrm{IO}$ and $2 \mathrm{I} \mathrm{d}$ and again between $2 \mathrm{I}$ and $3^{6} \mathrm{~d}$, but the latter was much greater. The increase in RNA per cell during suckling, followed by and overlapping the increase in protein per cell, correlates well with the period of increased morphological differentiation and maturation of function demonstrated between 14 and $35 \mathrm{~d}$ of age (Baxter \& Yoffey, 1948; Wacker, Zarkowsky \& Burch, I961; Goldstein, I971). The effects of the two types of malnutrition may be compared by expressing the differences between malnourished and control rats as 'deficit ratios' (Table 9). For example, DNA deficit ratio in protein-deficient rats =

Total DNA in controls of $36 \mathrm{~d}$-total DNA in protein-energy-deficient rats 
The effect of protein-energy malnutrition was to hinder cell division, as shown by a DNA deficit ratio of 0.43 , but the cells had little deficit in size, or in RNA or protein content. The effect of protein deficiency was different. There was a smaller deficit in cell number, but the cells were substantially smaller and had less RNA and protein per cell. The results may be explained by the phase of growth during which the respective insults were applied; in the energy-malnourished rats this occurred during maximal cell division and this process was inhibited, whereas in the protein-energy-deficient rats cell division was less affected, since the period of deprivation occurred at a time when the cells were dividing more slowly. It would be of interest to examine the effects of pure protein deficiency in the suckling rat and compare this with a deficiency of protein and energy in the immediate post-weaning period. These results would perhaps show whether changes in composition were the result of the type of malnutrition or the time at which the insult was applied.

Malnutrition in children or adults impairs the ability of the kidneys to respond to metabolic acidosis by increasing the urinary excretion of ammonia (Alleyne, I967; Klahr et al. 1970). The present results showed that in both types of malnutrition there was a marked increase in urinary ammonia when $\mathrm{NH}_{4} \mathrm{Cl}$ was given.

Renal gluconeogenesis was measured because it is related to the kidney's capacity to produce ammonia (Goodman, Fuisz \& Cahill, 1966; Alleyne \& Scullard, I969; Alleyne, 1970). It has been shown that most of the urinary ammonia is derived from the amide and amino groups of glutamine, and some of the remaining carbon skeleton is used to form glucose. Both groups of malnourished animals showed an increase in renal gluconeogensis after being made acidotic. In the protein-energy-deficient rats, however, the basal rate of gluconeogenesis was one-half that of the 36-d-old controls, the $2 \mathrm{I}$-d-old controls and the protein-energy-deficient rats. In spite of this, acidosis produced levels of gluconeogensis as high as those in normal rats.

The increase in renal gluconeogensis which occurs in acidotic animals is associated with an increased activity of the enzyme phosphoenolpyruvate carboxylase ( $E C$ 4.I.I.32) which cannot be prevented by inhibitors of protein synthesis such as actinomycin D or ethionine (Flores \& Alleyne, 197I). Longshaw, Alleyne \& Pogson (1972) have shown that this increased enzyme activity is partly caused by an inhibition of degradation of the enzyme, and there is no increased synthesis. In the protein-energy-deficient rat, protein synthesis is depressed and basal renal gluconeogenesis is low; it is of interest therefore that acidosis still evoked an increase in renal gluconeogenesis which presumably was also associated with increased activity of phosphoenolpyruvate carboxylase.

Protein-energy deficiency did, however, impair the capacity of the kidney to hypertrophy in response to acidosis. In the control animals the response was by hypertrophy rather than hyperplasia since protein and RNA increased without any increase in DNA. Lotspeich (1965) and Bignall, Elebute \& Lotspeich (1968) have shown that the renal hypertrophy which occurs in response to either acidosis or uninephrectomy may be additive if the animal is subjected to both stresses. Lotspeich (1965) speculated that renal hypertrophy which occurred in acidotic rats might be related to the increased need for ammonia synthesis and excretion, but in our protein-energy- 
deficient animals, although there was impairment of the capacity of the kidney to hypertrophy, urinary excretion of ammonia still increased when the animals were made acidotic.

We conclude that the $2 \mathrm{I}$-d-old, energy-malnourished rat has a severe deficit in renal cell number with little alteration in size or composition; the rat made protein-energy

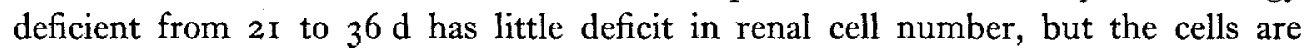
depleted of RNA and protein. Neither form of malnutrition inhibits the increase in urinary ammonia or renal gluconeogenesis which occurs when rats are made acidotic. Protein-energy deficiency does inhibit the renal hypertrophy which is a feature of the renal metabolic response to acidosis.

\section{REFERENCES}

Alleyne, G. A. O. (1967). Pediatrics, N.Y. 39, 400 .

Alleyne, G. A. O. (1970). F. clin. Invest. 49, 943 .

Alleyne, G. A. O. \& Scullard, G. H. (1969). F. clin. Invest. 48, ${ }_{3}^{6} 4$.

Baxter, J. S. \& Yoffey, J. M. (1948). F. Anat. 82, 189.

Bignall M. C., Elebute, O. \& Lotspeich, W. D. (1968). Am. F. Physiol. 215, 289.

Burch, H. B., Kuhlman, A. M., Skerjance, J. \& Lowry, O. H. (1971). Pediatrics, N. Y. 47, I 99.

Conway, E. J. (1957). Microdiffusion Analysis and Volumetric Error. London: Crosby, Lockwood and Son Ltd.

Dicker, S. E. (1950). Biochem. F, 46, 53 .

Enesco, M. \& Leblond, C. P. (1962). F. Finbryol. exp. Morph. ro, 530.

Flores, H. \& Alleyne, G. A. O. (1971). Biochem. F. 123, 35.

Flores, H., Sierralta, W. \& Monckeberg, F. (1970). $\mathcal{~ F . ~ N u t r . ~ 1 0 0 , ~} 375$.

Goldstein, L. (1971). Am. F. Physiol. 220, 2 13.

Goodman, A. D., Fuisz, R. E. \& Cahill, G. F. Jr (1966). F. clin. Invest. 45, 612.

Gordillo, G., Soto, R. A., Metcoff, J., Lopez, E. \& Antillon, L. G. (I957). Pediatrics, N. Y. $20,303$.

Huggett, A. St. G. \& Nixon, D. A. (1957). Lancet ii, 368.

Kennedy, G. C. (1958). 7. Endocr. 16, 9.

KIahr, S., Tripathy, K. \& Lotero, H. (1970). Am. F. Med. 48, 325.

Longshaw, I. D., Alleyne, G. A. O. \& Pogson, C. 1. (1972). F. clin. Invest. 51, 2284.

Lotspeich, W. D. (1965). Am. F. Physiol. 208, i I35.

Lowry, O. H., Rosebrough, N. J., Farr, A. L. \& Randall, R. J. (195I). F. biol. Chem. 193, 265.

Miller, S. A. (1969). In Mammalian Protein Metabolism Vol. 3, p. I 83 [H. N. Munro, editor]. New York and London: Academic Press.

Munro, H. N. \& Fleck, A. (1969). In Mammalian Protein Metabolism Vol. 3, p. 423 [H. N. Munro, editor]. New York and London: Academic Press.

Pricstley, G. C. \& Malt, R. A. (I968). F. Cell Biol. 37, 703.

Schneiden, H., Hendrickse, R. G. \& Haigh, C. P. (1958). Trans. R, Soc. trop. Med. Hyg. 52, I69.

Smith, R. (1959). Lancet i, 764 .

Spray, C. M. \& Widdowson, E. M. (1950). Br. F. Nutr. 4, 332.

Stern, I. \& Shapiro, B. (1953). F. clin. Path. 6, 158.

Wacker, G. R., Zarkowsky, H. S. \& Burch, H. B. (I96r). Am. F. Physiol zoo, 367.

Widdowson, E. M., Dickerson, J. W. T. \& McCance, R. A. (1960). Br. F. Nutr. 14, 457.

Widdowson, E. M. \& McCance, R. A. (ig60). Proc. R. Soc. B I52, I88.

Winick, M. \& Noble, A. (r 965$)$. Devl Biol. x2, $45^{\mathrm{r}}$. 